\title{
MULTIFREQUENCY RADAR OBSERVATIONS COLLECTED IN SOUTHERN FRANCE DURING HYMEX-SOPI
}

by O. Bousquet, A. Berne, J. Delanoe, Y. Dufournet, J. J. Gourley, J. Van-Baelen, C. Augros, L. Besson, B. Boudevillain, O. Caumont, E. Defer, J. Grazioli, D. J. Jorgensen, P.-E. Kirstetter, J.-F. Ribaud, J. Beck, G. Delrieu, V. Ducroce, D. Scipion, A. Schwarzenboeck, and J. Zwiebel

An ambitious radar deployment to collect high-quality observations of heavy precipitation systems developing over and in the vicinity of a coastal mountain chain is discussed.

T he accurate prediction of orographic convective precipitation is a major meteorological challenge that depends on a wide range of time and space scales as well as complex processes ranging from moist orographic airflow dynamics to cloud microphysics. Forecasting the location and amount of heavy precipitation is particularly critical in coastal mountainous regions. Heavy precipitation can indeed generate rapid and destructive floods, and thus it represents a major threat to lives and infrastructure, especially since communities living in foothill regions have experienced large population increases. Several important field and research programs, such as the Mesoscale Alpine Programme (MAP; Bougeault et al. 2001), the Intermountain Precipitation Experiment (IPEX; Schultz et al. 2002), and the Improvement of Microphysical Parameterization through Observational Verification Experiment (IMPROVE; Stoelinga et al. 2003), among others, have been designed in the last decade to improve the understanding and prediction of orographically generated precipitation. Although the analysis of datasets collected during these field campaigns has dramatically advanced our understanding of moist dynamics and microphysics over complex terrain (e.g., Medina et al. 2005; Rotunno and Houze 2007), our knowledge of coastal orographic precipitation remains insufficient to satisfy societal demands for precise forecasts and warnings.

A fundamental element that has been missing in past field experiments is nearly simultaneous measurements of the moist marine inflow as a function of time, height, and along-barrier distance with measurements of precipitation over orography in addition to turbulence/microphysical transformations occurring in between. The Hydrological Cycle in the Mediterranean Experiment (HyMeX) field campaign (Ducrocq et al. 2014), which is dedicated to the study of the water cycle in the northwestern Mediterranean basin, intends to achieve this goal and to gather such basic but hard-to-obtain information.

High-resolution dual-Doppler and dualpolarization radar measurements are key to resolving small-scale precipitation and flow structures and to studying the role of complex topography and microphysical processes in precipitation formation and enhancement. During the first special 
observing period (SOP 1; fall 2012) of HyMeX, which principally focused on investigating the influence of mountain topography on moist dynamics and cloud microphysics, important efforts have thus been made to achieve comprehensive weather radar coverage. In southern France, the HyMeX radar network was specifically designed to collect high-quality observations of thunderstorms and precipitation systems developing over and in the vicinity of the Massif Central mountain chain to document the characteristics of the hydrometeors forming within the moist upstream flow impinging on the Cévennes area.

Observations collected in this framework will provide for the investigation of the microphysics and dynamics of mesoscale convective systems (MCSs) developing in this flood-prone area, and will be used to develop and evaluate innovative radar-based products for numerical weather prediction (NWP) and hydrological applications. A description of this observing network is given herein together with a discussion of potential research studies inferred from the preliminary analysis of radar data collected during HyMeX SOP 1.

\section{THE HYMEX EXPERIMENTAL RADAR} NETWORK IN SOUTHERN FRANCE. The precipitation observing network deployed in southern France during HyMeX (Fig. 1) consists of a combination of disdrometers and weather radars operating at

AFFILIATIONS: BOUSQUET-Laboratoire de L'Atmosphère et des Cyclones, UMR 8I05, Saint-Denis, France; Berne AND GrazıoliEnvironmental Remote Sensing Laboratory, École Polytechnique Fédérale de Lausanne, Lausanne, Switzerland; Delanoe AND BESSON-LATMOS, UMR 8190, Guyancourt, France; DUFOURNETDelft University of Technology, Delft, Netherlands; GOURLEY, Jorgensen, AND KiRSTETTER—NOAA/NSSL, Norman, Oklahoma; Van-Baelen, Schwarzenboeck, and ZWiebel一LaMP, UMR 6016, Clermont Ferrand, France; Augros, Caumont, Ribaud, Beck, AND DuCROCQ-CNRM-GAME, UMR 3589, Toulouse, France; BoudeVillain and Delrieu—LTHE, UMR 5564, Grenoble, France; Defer-LERMA, Paris, France; SCIPION-Radio Observatorio de Jicamarca, Instituto Geofísico del Perú, Lima, Perú CORRESPONDING AUTHOR: Olivier Bousquet, Laboratoire de L'Atmosphère et des Cyclones, UMR 8105, 15 Avenue René Cassin, CS 92003, 97744 St-Denis CEDEX 9, France

E-mail: olivier.bousquet@meteo.fr

The abstract for this article can be found in this issue, following the table of contents.

DOI:10.1175/BAMS-D-13-00076.I

A supplement to this article is available online (I0.II75/BAMS-D-13-00076.2)

In final form 15 June 2014

(C)2014 American Meteorological Society
$\mathrm{S}, \mathrm{C}, \mathrm{X}, \mathrm{Ku}$, and $\mathrm{W}$ bands (a detailed description of these instruments is in Table ES1, available online at http://dx.doi.org//0.II75/BAMS-D-13-00076.2). All these sensors were deployed within a $90,000-\mathrm{km}^{2}$ domain encompassing the Rhone Valley and extending northward from the Mediterranean Sea to the Massif Central and eastward from the Massif Central to the French Alps.

The core of the radar network is based on a subsample of the French operational radar network Application Radar à la Météorologie Infrasynoptique (ARAMIS; Fig. 1a). It comprises six radars operating at $\mathrm{C}$ and $\mathrm{S}$ bands, which cover the French coastal Mediterranean region with an average radar baseline of $150 \mathrm{~km}$, and two X-band polarimetric radars deployed in the southern Alps under the auspices of the Risques Hydrométéorologiques en Territoires de Montagnes et Méditerranéens (RHYTMME) project (Beck and Bousquet 2013). During the experimental phase, additional dual-Doppler and dual-polarization radar coverage was also required to more explicitly resolve small-scale microphysical and dynamical processes in complex terrain as well as to collect high-resolution data in areas not well covered by the operational radars. Four transportable X-band scanning weather radars were thus deployed at various locations of the Cévennes-Vivarais area (Fig. 1b) to obtain hydrometeor type, reflectivity, and Doppler velocity measurements in both volume and rangeheight indicator (RHI) scanning mode.

The NOXP polarimetric Doppler radar, operated by the U.S. National Severe Storms Laboratory (NSSL), was deployed near the foothills of the Massif Central on the top of Mount Bouquet (600 m MSL). This site, located at an equal distance $(\sim 40 \mathrm{~km})$ between the Bollène and Nîmes operational S-band radars, was chosen to allow for high-resolution multiple-Doppler analysis of radar data over an area that is particularly prone to extreme flash floods (Delrieu et al. 2005).

Another mobile Doppler polarimetric radar, MXPOL, was deployed farther north in the vicinity of a high-resolution Hpiconet network (a dense network of rain gauges and disdrometers over a watershed, indicated by the red rectangle in Fig. 1b). This radar, operated by École Polytechnique Fédérale de Lausanne (EPFL, Switzerland), focused on obtaining microphysical characteristics of clouds and precipitation in terms of drop size and shape distribution with an emphasis on shallow orographic rainbands that develop over the Cévennes.

Two fast-scanning "conventional" radars (X1 and X2) operated by the French Laboratoire de 
Météorologie Physique (LaMP) were also deployed in the northern part of the domain to study the variability of rain at the precipitation cell scale and at high temporal resolution $(<1 \mathrm{~min})$. These two radars were positioned at La Bombine, a site located on the Cévennes ridge at about $1000 \mathrm{~m} \mathrm{MSL}$ and approximately $10 \mathrm{~km}$ away from the observed maximum climatological rainfall, and at Le Chade, within the Hpiconet area, respectively.

The radar network was completed by radars profilers deployed throughout the area to investigate space-time variability of precipitation as a function of along-barrier distance. These include an ensemble of six Micro Rain Radars (MRR; Löffler-Mang et al. 1999) extending from the Mediterranean coast to the Massif Central, to collect high-resolution microphysical and kinematic measurements along a coarse cross-barrier transect on the windward slope (southeastern foothills of the Massif Central), and the S-band, dual-polarimetric Transportable Atmospheric Radar (TARA; Unal 2009; Dufournet and Russchenberg 2011), operated by the Delft University of Technology.

Finally, a network of disdrometers composed of 27 Particle Size and Velocity (PARSIVEL; LöfflerMang and Joss 2000) disdrometers and two twodimensional video disdrometers (2DVD; Kruger and Krajewski 2002) was also installed to complement the already dense surface observation network available over the area (Delrieu 2003). The 2DVD provides information about the shape of hydrometeors through recording two orthogonal side views of every particle falling through a $10 \times 10 \mathrm{~cm}^{2}$ sampling area. The PARSIVEL is an optical disdrometer (OD) with a sampling area of $\sim 50 \mathrm{~cm}^{2}$, which is commonly used to investigate the microstructure of rainfall. About half of the disdrometers were concentrated in the northern part of the experimental domain, within the $\sim 35-\mathrm{km}^{2}$ Hpiconet area. The remaining disdrometers were deployed at various locations along the MRR transect.

This experimental setup was also complemented by the $95-\mathrm{GHz}$ airborne Radar System Airborne (RASTA) cloud radar (Protat et al. 2009) on board the French Falcon 20 (F20) aircraft. About half of the 20 missions flown by this aircraft were conducted over southern France, allowing for gathering information about the physical and radiative properties of ice particles. 
Examples of data collected by these various sensors in a variety of weather situations, including a long-lasting bow echo system (IOP 6, 24 September 2012), a frontal system associated with embedded convection (IOP 8, 29 September 2012), and a fastmoving isolated thunderstorm (IOP 16, 21 October 2012), are presented herein.

\section{HIGH-RESOLUTION OBSERVATIONS OF CLOUD DYNAMICS AND MICROPHYSICS.}

An important asset of HyMeX is the ability to gather observations at the microphysical scale from the TARA and RASTA high-resolution radar profilers. These instruments are capable of observing the microphysical properties of precipitation at very high spatial and temporal resolutions-that is, $30 \mathrm{~m}$ in range every $3 \mathrm{~s}$ for TARA and $120 \mathrm{~m}$ every
$1.5 \mathrm{~s}$ for RASTA - and thus are particularly suited to complement storm-scale and mesoscale observations provided by scanning weather radars. Both instruments have multibeam capability.

TARA (Unal et al. 2012) is an S-band (3.298 GHz) ground-based profiling radar with flexible antenna elevation, based on the frequency-modulated continuous wave (FMCW) principle. The antenna system includes three feeds: a dual-polarized on-focus feed, which is directed along the axis of symmetry of the parabolic reflector (i.e., $45^{\circ}$ ), and two offset feeds that produce single-polarized beams at $15^{\circ}$ angles to the main beam to achieve three-dimensional wind speed measurements (additional information about TARA can be found online in Table ES2 at http://dx.doi.org//0.1/75 /BAMS-D-I3-00076.2).
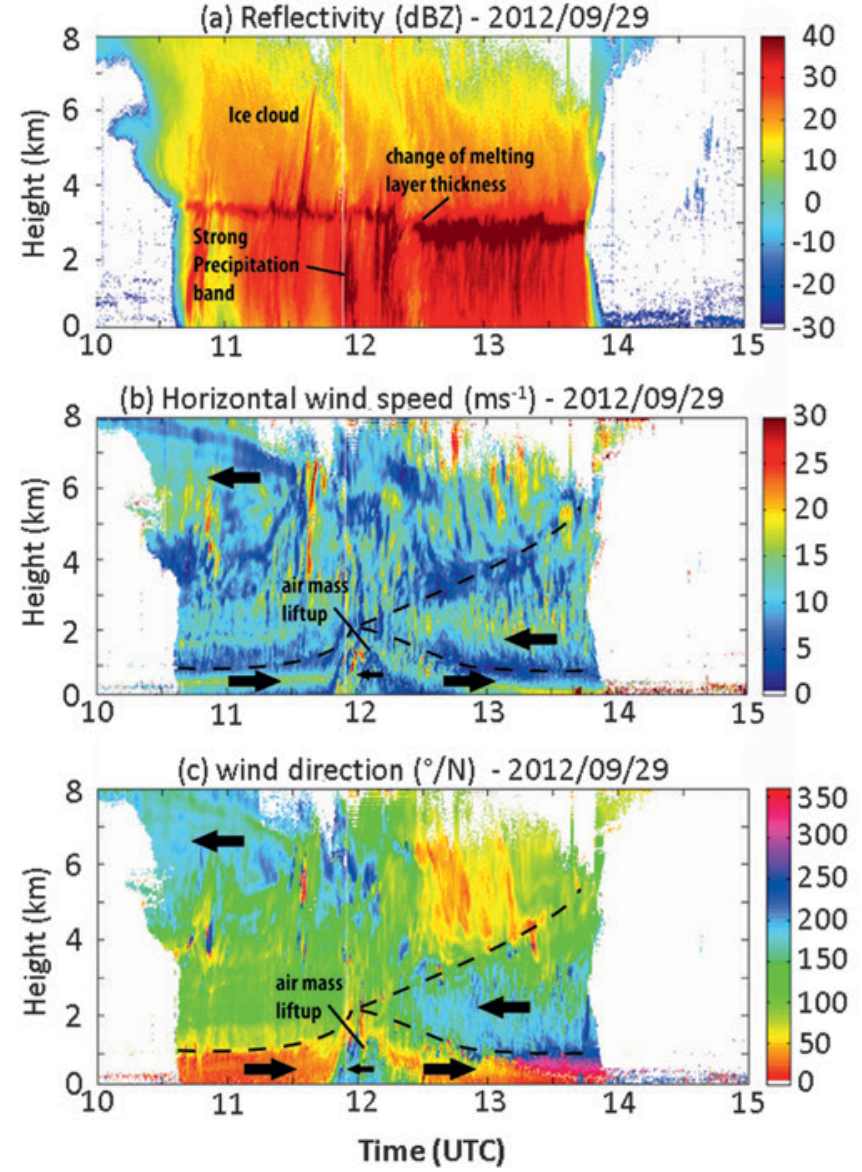

(d) sZdr shifted (dB) - 10:55:50 UTC

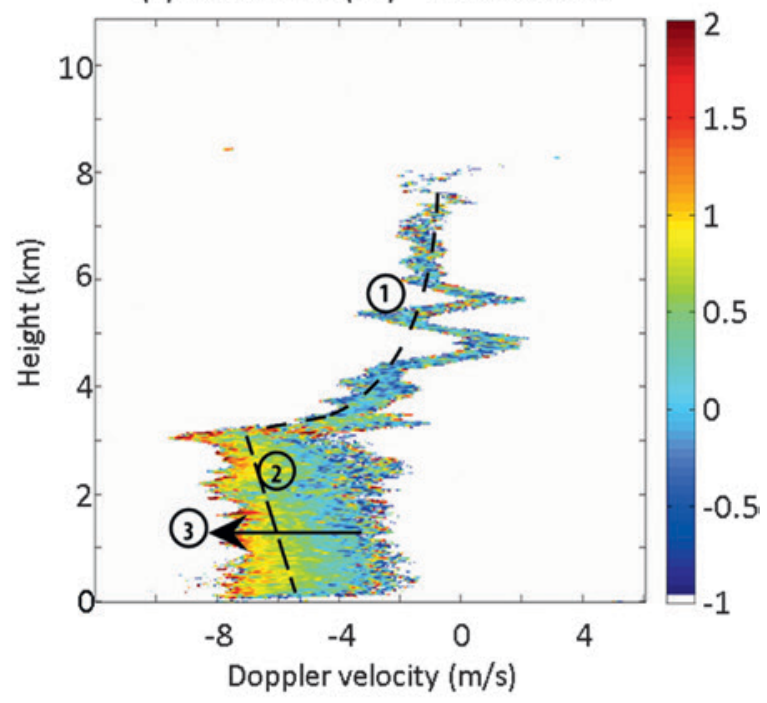

FIG. 2. TARA observations made on 29 Sep 2012 (IOP 8) over a 5-h period starting at 1000 UTC. Time series of (a) reflectivity, (b) horizontal wind speed, (c) wind direction, and (d) $Z_{\mathrm{DR}}$ spectrogram retrieved at 1055 UTC with negative velocities referring to falling particles. Reflectivity observations allow for monitoring the evolution of the precipitation regime (changes in melting-layer thickness and vertical rainband variability), while dynamical information allows for discriminating between air masses (as indicated by black arrows), the transitions being

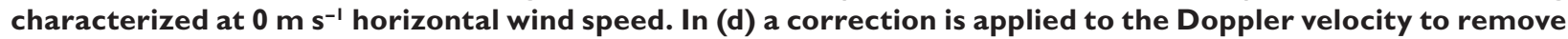
the contribution of the horizontal wind component. Because of heavy turbulence and strong wind shear in the cloud region, this correction artificially produces the zigzag structure seen on the spectrogram. 
An example of TARA capabilities is provided in Fig. 2 using data collected during the IOP 8 frontal precipitation event (29 September 2012). The time series of observed reflectivity (Fig. 2a), horizontal wind speed (Fig. 2b), and wind direction (Fig. 2c) allow the evolution in precipitation processes to be observed for a 5-h period (1000-1500 UTC) and provide the ability to highlight differences between precipitation and cloud areas during the passage of a frontal system. TARA observations also provide insights into microphysical processes active within clouds, as illustrated by the differential reflectivity $\left(Z_{\mathrm{DR}}\right)$ spectrogram shown in Fig. 2d. In this figure, $Z_{\mathrm{DR}}$ values (related to particle shape) at each height bin are expressed in terms of Doppler velocity, which provides information about the particle fall velocity and, to a further extent, the particle size and density distribution. From this particular example, one can, for instance, notice 1) an increase of ice particle size in the cloud region (related to the increase of Doppler velocity values), 2) a slight decrease of raindrops size while following toward the ground, and 3) a change in shape of the raindrops from spherical to oblate as the Doppler velocity (and therefore size) increases.

RASTA is a cloud radar that can be either operated from the ground or from a mobile platform. During HyMeX, it was operated on board the French Falcon 20 research aircraft (see Table ES3 in the online supplement at http://dx.doi.org/I0.II75/BAMS -D-13-00076.2 for more information about this radar). The airborne version of RASTA has a unique configuration, which consists of six antennas-three looking downward and three looking upwardproviding $3 \mathrm{D}$ observations of the dynamics and the microphysics of clouds above and below the flight track. Once the cross track, along track, and vertical wind fields are retrieved, one can estimate the terminal fall velocity $\left(V_{t}\right)$, which is then combined with radar reflectivity to compute microphysical properties of observed clouds, such as ice water content (IWC), ice particle density, and effective radius (Delanoë et al. 2007). Examples of RASTA observations obtained during IOP 8 are shown in Fig. 3.

All in all, TARA can monitor the temporal evolution of cloud processes by observing the same atmospheric column at high temporal resolution, while RASTA can be used to provide accurate spatial distribution of such processes over a larger area of interest. This complementarity shall be investigated in the near future by using RASTA data collected during the numerous passages of the F20 aircraft over TARA (e.g., Fig. 3e).
RETRIEVAL OF RAINFALL DSDS. The disdrometer network was deployed to monitor the variability of drop size distribution (DSD) at ground level as well as to provide relevant information for both polarimetric radar data interpretation and radar rainfall estimation assessment. Collected DSD data can be used to evaluate the performance of radar-based DSD retrieval algorithms as well as to establish local power laws adapted to the Cévennes area for the interpretation of radar observations. This potential is illustrated in Fig. 4, which shows the temporal evolution of the rainfall rate, the total drop concentration, and the median volume diameter as observed by disdrometers along the south-north MRR transect (Fig. 1b) and within the Hpiconet area on 29 September 2012 (IOP 8). The large distances between Candillargues, Alès, and the HPiconet area (Fig. 1b) generate a clearly visible time shift in DSD evolution. The small-scale variability of the DSD is illustrated by the range of values measured by the different disdrometers within the Hpiconet network.

\section{EVALUATION OF HYDROMETEOR CLASSIFICATION ALGORITHMS (HCA).}

A major advantage of radar polarimetry is the ability to infer the species of hydrometeors composing precipitating systems. This capability is important to attain many objectives of the HyMeX research program, such as the evaluation of new microphysical schemes developed for high-resolution NWP systems, the investigation of relationships between radar observables and variables of interest (e.g., rain intensity), and between cloud microphysics and lightning activity (see below). In this regard, a particular emphasis was put on the evaluation and improvement of hydrometeor classification algorithms at X,-C-, and S-band frequencies.

Figure 5 presents preliminary results of an ongoing study focusing on evaluating the consistency of microphysical retrievals at $\mathrm{C}$ band (Montclar radar) and $\mathrm{S}$ band (Nimes radar) by comparing microphysical retrievals within a common sampling area of the two radars. The fuzzy logic algorithm used in this study is based upon the approaches proposed by Al-Sakka et al. (2013), Dolan et al. (2013), Park et al. (2009), and Marzano et al. (2006). It discriminates between six hydrometeor species (rain, wet snow, dry snow, ice, graupel, and hail) at S, C, and X bands. Overall, the fraction of hydrometeor types inferred from the global analysis of $4 \mathrm{~h}$ of radar data collected during IOP 8 (Fig. 5b) show good consistency despite the different wavelengths and slightly different beam properties of the two radars $\left(1.1^{\circ}\right.$ vs $1.25^{\circ}$ beamwidth). 
The time series of hydrometeor species retrieved from the two radars by steps of $5 \mathrm{~min}$ (Figs. $5 \mathrm{c}, \mathrm{d}$ ) are also generally in good agreement, although some dissimilarity could be observed around 1400 UTC. Note that a complete volume scan is composed of three different 5-min cycles that are repeated every $15 \mathrm{~min}$. On the Nimes and Montclar radars, only the highest elevation plan position indicators (PPIs) go up high enough to sample ice over the intercomparison area. These PPIs are only performed during the first 5-min cycle, which explained why ice is only detected every $15 \mathrm{~min}$.

To better quantify the performance of this, or other, HCA, statistical studies and systematic comparisons with in situ [Forward Scattering Spectrometer Probe 100 (FSSP-100), Precipitation Imaging Probe (PIP), 2D stereo (2-DS) probe] data will be conducted using flight-level data collected during all F20 missions flown over France. Detailed radar intercomparisons will also be reinforced and a)

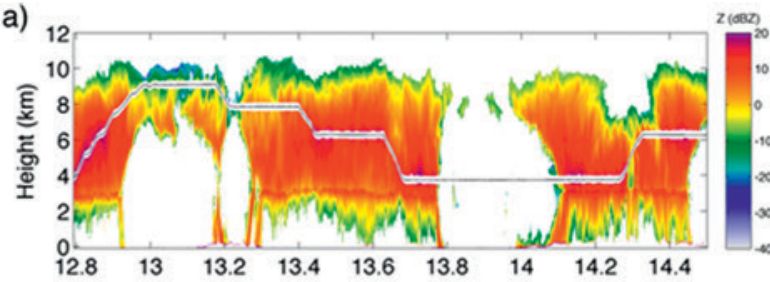

b)

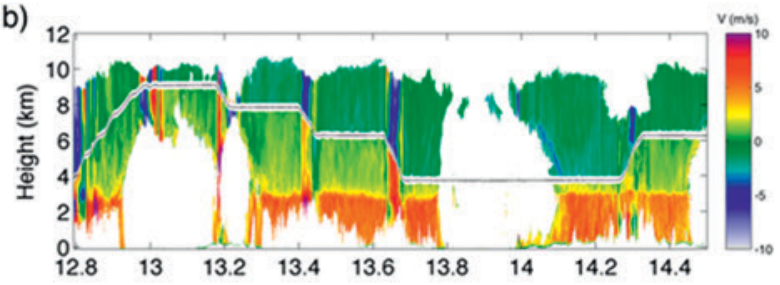

c)

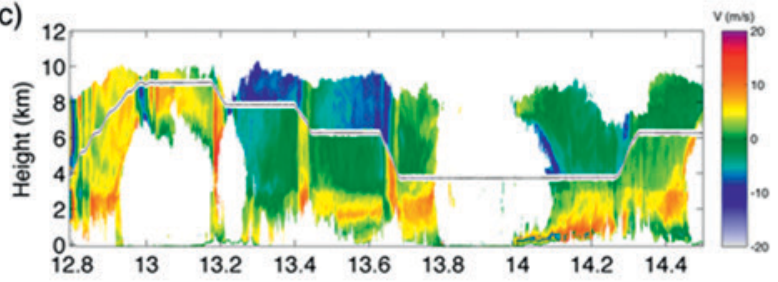

d)

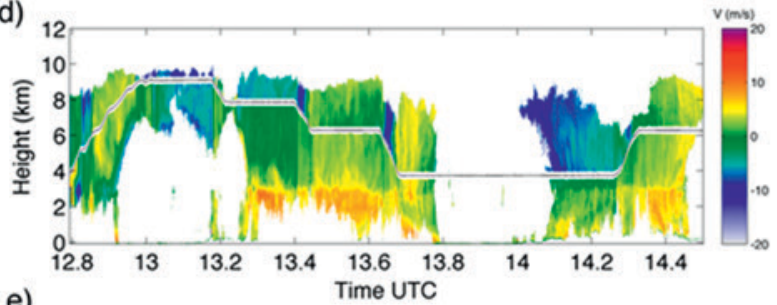

e)

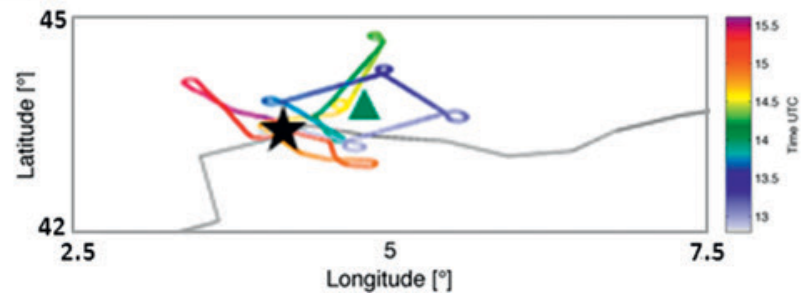

f)

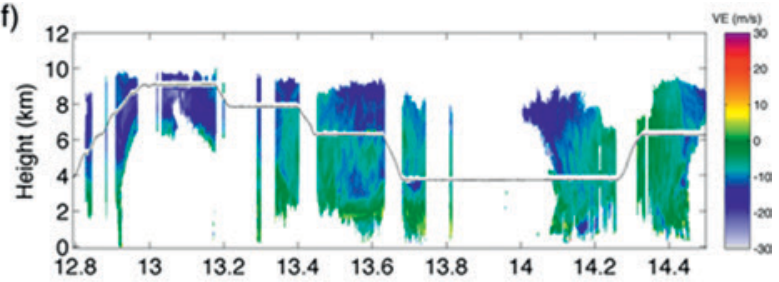

g)

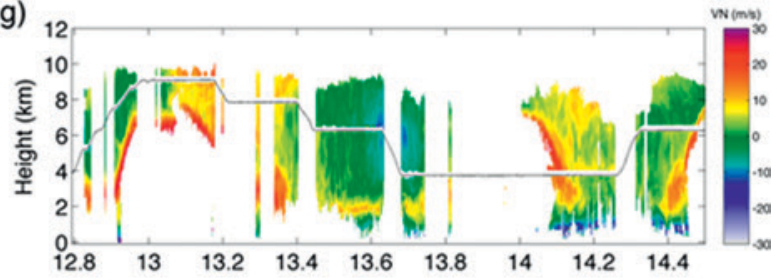

h)

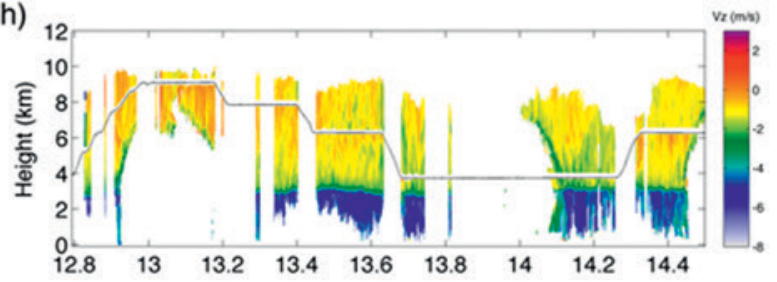

i)

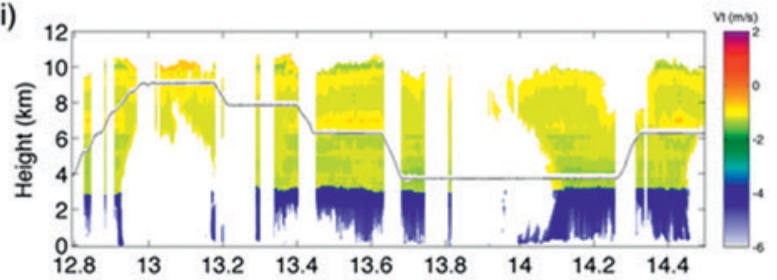

j)

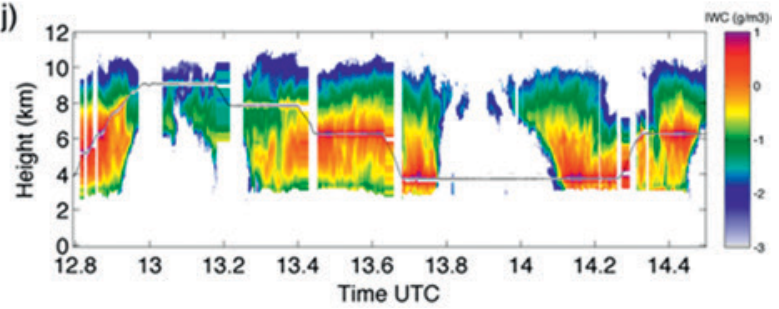

Fig. 3. Example of RASTA measurements and retrieval products made on 29 Sept 2012 (IOP8). (a) The vertical reflectivity measured by the nadir and zenith antennas. Measured radar radial velocities corresponding to (b) vertical, (c) backward, and (d) transverse antennas. (e) Several stack legs at different levels were carried out in the area of Montpellier around the Candillargues supersite. Retrieved (f) zonal and (g) meridional components of the wind. Retrieved $(h)$ vertical wind $\left(V_{z}\right)$ and (i) hydrometeors' terminal fall velocity $\left(V_{t}\right)$, and $(j)$ IWC. The white line in all panels shows the projection of the flight track in the vertical plane. In (e) the black star and the green triangle indicate the locations of TARA and the Nimes radar, respectively. 
expanded by taking the research polarimetric X-band radars National Oceanic and Atmospheric Administration (NOAA) X-Pol (NOXP) and MXPOL into account in the analysis.

\section{REAL-TIME 3D WIND} RETRIEVAL. The ability to perform multipleDoppler wind synthesis from operational weather radar systems on a realtime basis was investigated by the French weather service Météo-France in 2006 using a network of six Doppler radars covering the greater Paris area (Bousquet et al. 2007, 2008b). In preparation for the field phase of HyMeX, this analysis was tested over regions of complex terrain of southern France (Beck and Bousquet 2013) before being eventually extended to the entire French radar network, so as to produce a nationwide $3 \mathrm{D}$ reflectivity and wind field mosaic (Bousquet and Tabary 2014). During the HyMeX field phase, a special version of this radar mosaic was used to guide the Falcon 20 research aircraft over the Cévennes and Rhone Valley areas. MultipleDoppler wind (MDW) and reflectivity fields were produced in real time every 15 min over a domain of $200 \mathrm{~km} \times 200 \mathrm{~km}$ using the $\mathrm{C}$ and $\mathrm{S}$ band operational radars shown in Fig. 1a.

Figure 6 presents examples of real-time, highresolution $\left(1 \mathrm{~km}^{2}\right)$, multiple-Doppler analyses of radar data collected within the bow echo observed during HyMeX IOP 6. At the time of observations, the MCS exhibited many common characteristics of bow echo systems (Fujita 1978; Davis et al. 2004), such as a strong $\left(24 \mathrm{~m} \mathrm{~s}^{-1}\right), 5-\mathrm{km}$-deep subsiding rear-to-front (RTF) inflow jet, cyclonic and anticyclonic bookend vortices, and strong vertical motion $\left(>12 \mathrm{~m}^{-1}\right)$ along the leading edge, in addition to
Rain rate by station during HYMEX SOP

2012-09-29 10:30:00 to 2012-09-29 15:50:00
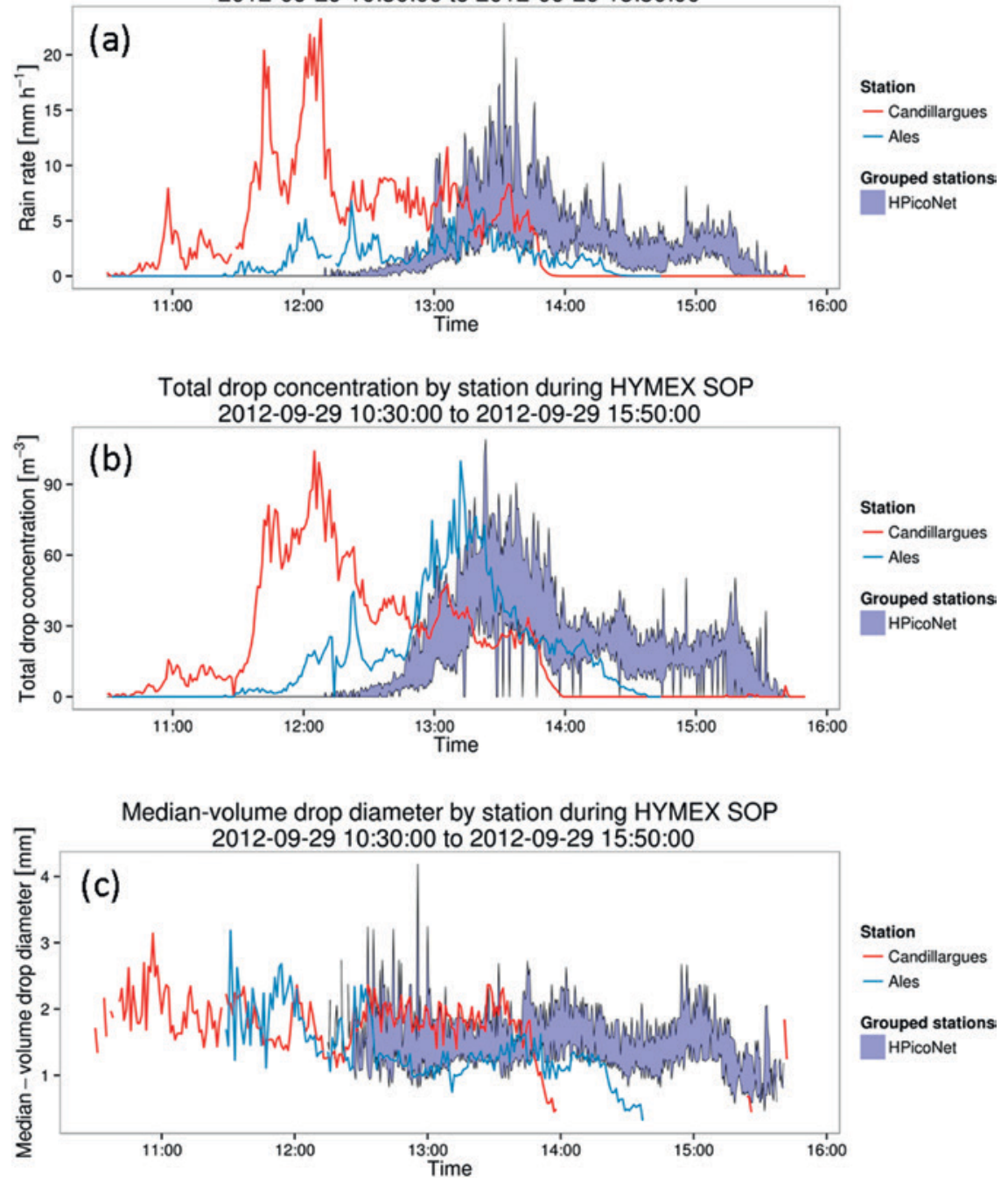

FIG. 4. Time series of (a) rain rate, (b) total drop concentration, and (c) medianvolume drop diameter as derived from optical disdrometer measurements at Candillargues (red), Alès (light blue), and all sensors deployed in the Hpiconet (purple) from 1030 to I550 UTC 29 Sep 20I2. See Fig. I for locations.

strong deep convection with reflectivity values of $25 \mathrm{dBZ}$ up to $12 \mathrm{~km} \mathrm{MSL}$. In the near future, these high-quality wind fields will be further improved by incorporating research radar data collected during SOP 1 into the analysis. In addition to providing insights about the dynamics of MCSs sampled during HyMeX, MDW will also be used to assess (and eventually correct) numerical model forecasts through identifying possible temporal or spatial phase shifts in model outputs (e.g., Beck et al. 2014; Bousquet et al. 2008a).

The HyMeX field campaign also represents a unique opportunity to compare MDW fields with independent measurements, such as in situ or airborne radar data. With this regard, a comparison 
between MDW and RASTA winds measured during the IOP 6 flight is presented in Fig. 7. Overall, one can notice a good agreement between the two datasets, although RASTA-derived winds obviously show more (a) 13:45 UTC

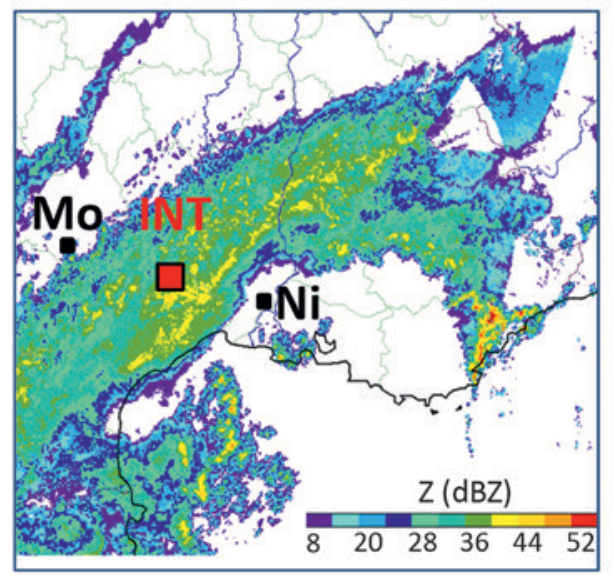

(b)

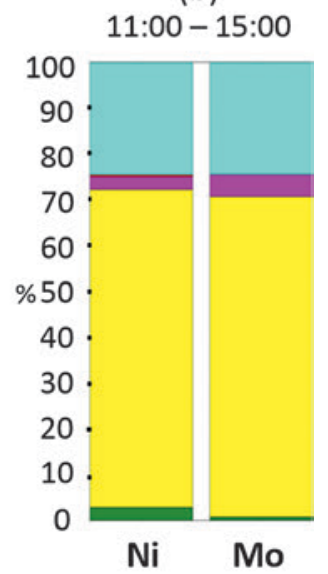

(c) Nimes (Ni)

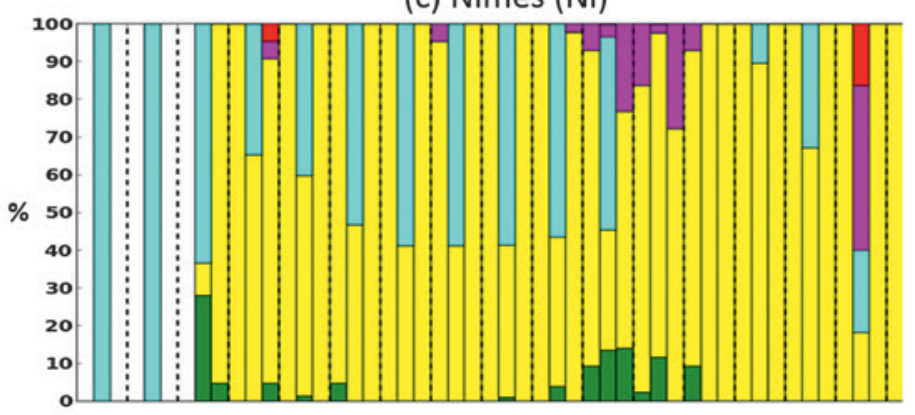

(d) Montclar (Mo)

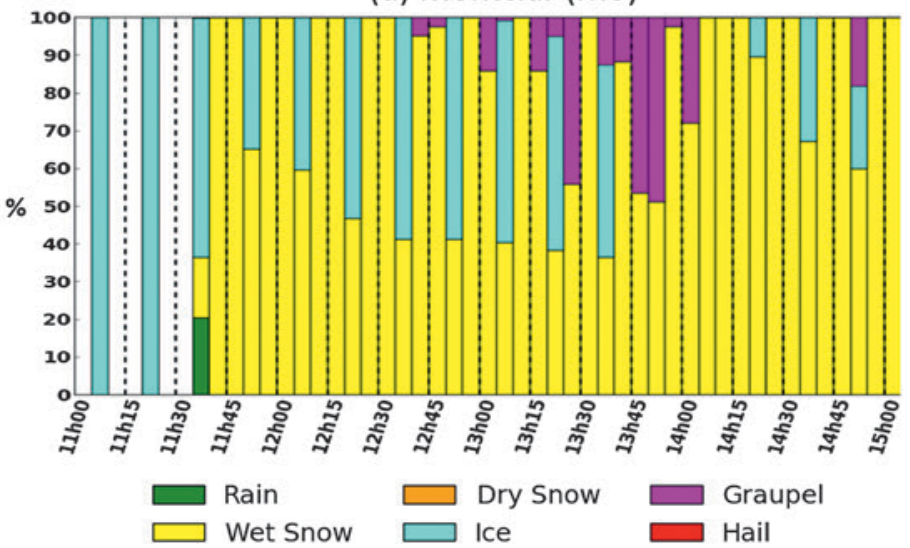

FIG. 5. (a) Operational reflectivity composite over southern France valid at 1345 UTC 29 Sep 2012. (b) Fraction of hydrometeor species retrieved from Nimes ( $S$ band) and Montclar (C band) radars between 1100 and 1500 within a $25-\mathrm{km}^{2}$ intercomparison area [red square in (a)]. Results are shown for (b) the whole period, and by steps of $5 \mathrm{~min}$ for (c) Nimes and (d) Montclar. In (a) labels $\mathrm{Ni}$ and Mo indicate the location of the Nimes and Montclar radars, respectively. Within the intercomparison area, the Mo and $\mathrm{Ni}$ radar beams intersect at $~ 3,7$, and $9 \mathrm{~km}$ MSL. The two radars are separated by $150 \mathrm{~km}$. details because of the superior resolution of airborne measurements $(\Delta h=500 \mathrm{~m}, \Delta z=120 \mathrm{~m})$ with respect to ground-based observations $(\Delta h=1000 \mathrm{~m}$, $\Delta z=500 \mathrm{~m})$. Such comparisons between MDW- and RASTA-derived winds will be performed for all RASTA flights conducted over France, so as to evaluate ground-based and airborne wind retrievals over the plain and high terrain.

\section{SYNERGY BETWEEN RADAR AND LIGHTNING OBSERVA-} TIONS. Observations collected during HyMeX also offer a unique opportunity to investigate the relationships between microphysics, dynamics, electrification, and lightning occurrence in storms that were observed in southern France. Indeed, during SOP 1, total lightning activity, including intracloud (IC) and cloud-toground (CG) flashes, and electrical properties of storms were recorded with a Lightning Mapping Array (LMA; Rison et al. 1999) composed of 12 stand-alone stations, several operational lightning locating systems [e.g., European Cooperation for Lightning Detection (EUCLID)], and a set of ground-based research instruments (electric field sensors, acoustics sensors, video cameras) deployed throughout the experimental area.

Different types of convection from early to decaying stages were documented over land and over sea with the LMA. An example of concurrent observations within the IOP 6 storm from 0215 to 0230 UTC is shown in Fig. 8. At this time, the lightning activity was distributed more or less along a north-south direction and extended farther north outside the LMA network. It was principally located to the west of significant updrafts, as retrieved from radar observations (Figs. 8b,c). The deepest convective cell was recorded south of the system with lightning observed up to a height of $12 \mathrm{~km}$ MSL (Fig. 8e). In this thunderstorm, preliminary analysis of the lightning data suggests that the IC-CG ratio was 110:14 for the period 0225-0230, where $64 \%$ of CG flashes were of negative polarity. For the studied core, electrical discharges were recorded mainly in cloud regions with reflectivity above $20 \mathrm{dBZ}$. 
Another interesting example illustrating the potential of polarimetric radar observations for lightning studies and vice versa was sampled by NOXP on 21 October 2012 (Fig. 9). At the time of observations, the radar data indicated an intense cell characterized by significant signal loss in the liquid phase of precipitation at lower elevation angles. Above the melting layer, $Z_{\mathrm{DR}}$ presents an interesting positive-negative couplet associated with a decreasing differential phase $\left(\Phi_{\mathrm{DP}}\right)$ in the radial direction. This signature is the result of cross coupling between orthogonally polarized waves when the radar is operating in simultaneous transmission and reception (STAR) mode. Radial streaks in $Z_{\mathrm{DR}}$ and $\Phi_{\mathrm{DP}}$ at heights of $7-10 \mathrm{~km}$ have been attributed to ice crystals oriented by electrostatic fields in regions of storm electrification (Ryzhkov and Zrnić 2007; Hubbert et al. 2010). While these depolarization signatures, which can cause bias in $Z_{\mathrm{DR}}$, are usually considered undesirable (Hubbert et al. 2010), they can also be used as an indicator of strong electrification and thus be used as an opportunity to detect charged ice particles in absence of a lightning detection sensor.

As it is believed that lightning frequency is proportional to the product of the downward mass flux of graupels and of the upward mass flux of ice crystals (Deierling et al. 2008), statistical analyses of LMA data combined with ice flux and mass budgets inferred from dualpolarimetric radar observations, MDW analyses, and exploitation of the vertical profile of reflectivity
(VPR) polarimetric models (e.g., Kirstetter et al. 2013) will be relied upon to investigate relationships between dynamics, microphysics, and lightning activity. These results will also be used to evaluate the explicit lightning scheme Cloud Electrification and Lightning Scheme (CELLS) recently implemented in the Méso-NH research model (Barthe et al. 2012; Pinty et al. 2013).
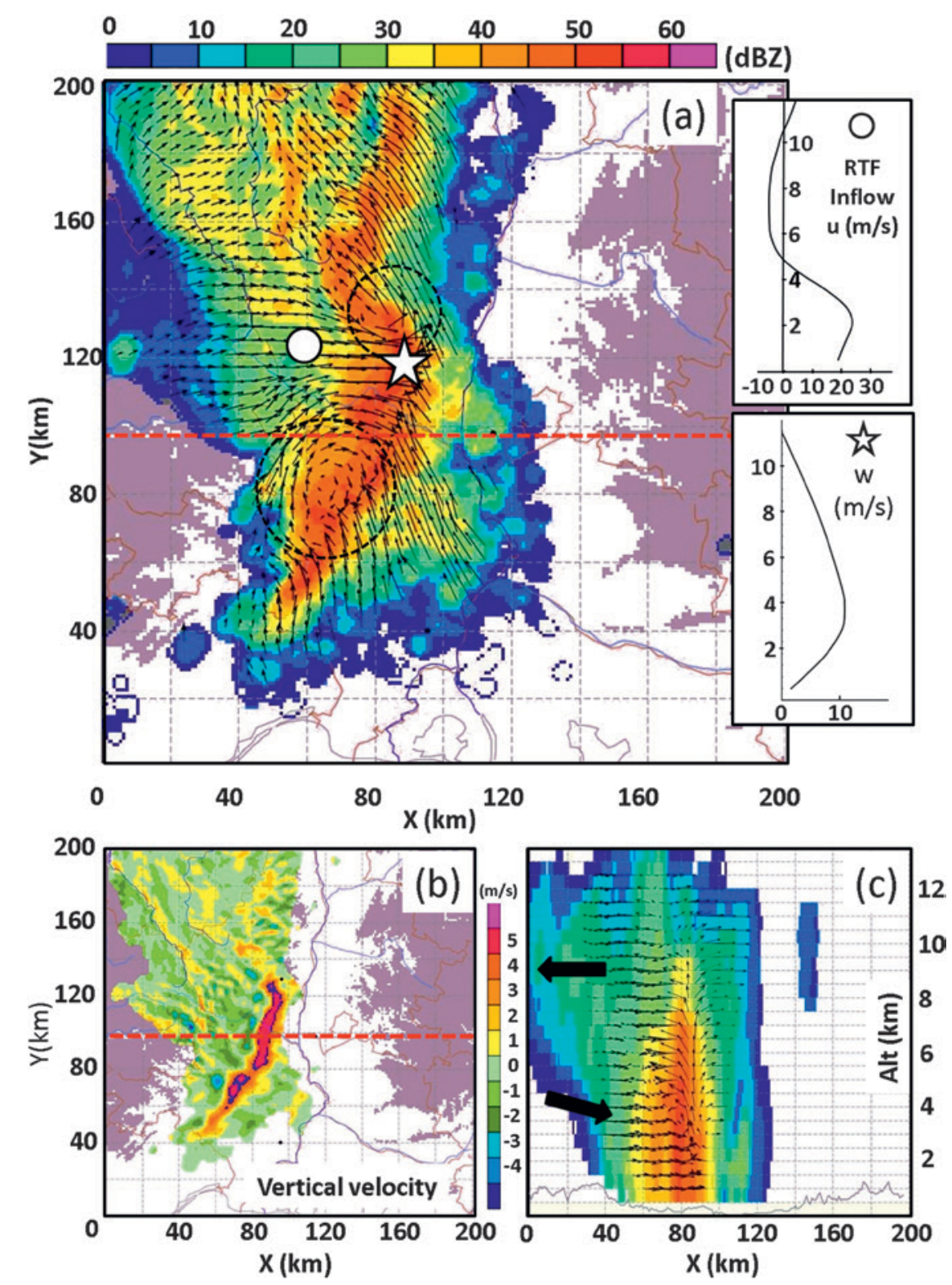

FIG. 6. (a) Horizontal cross section of multiple-Doppler system-relative wind field and reflectivity at $2 \mathrm{~km}$ MSL and 0230 UTC 24 Sep 2012, (b) vertical velocity, and (c) vertical cross section of reflectivity and MDWs along the red dashed line shown in (a) and (b). The insets in (a) show (bottom, star) vertical profiles of vertical velocity within the convective area of the system and (top, circle) zonal wind component within the subsiding RTF inflow area. Dashed black circles in (a) show the location of anticyclonic (bottom) and cyclonic (top) vortices. Purple shadings in (a) and (b) show terrain height above $500 \mathrm{~m}$. 

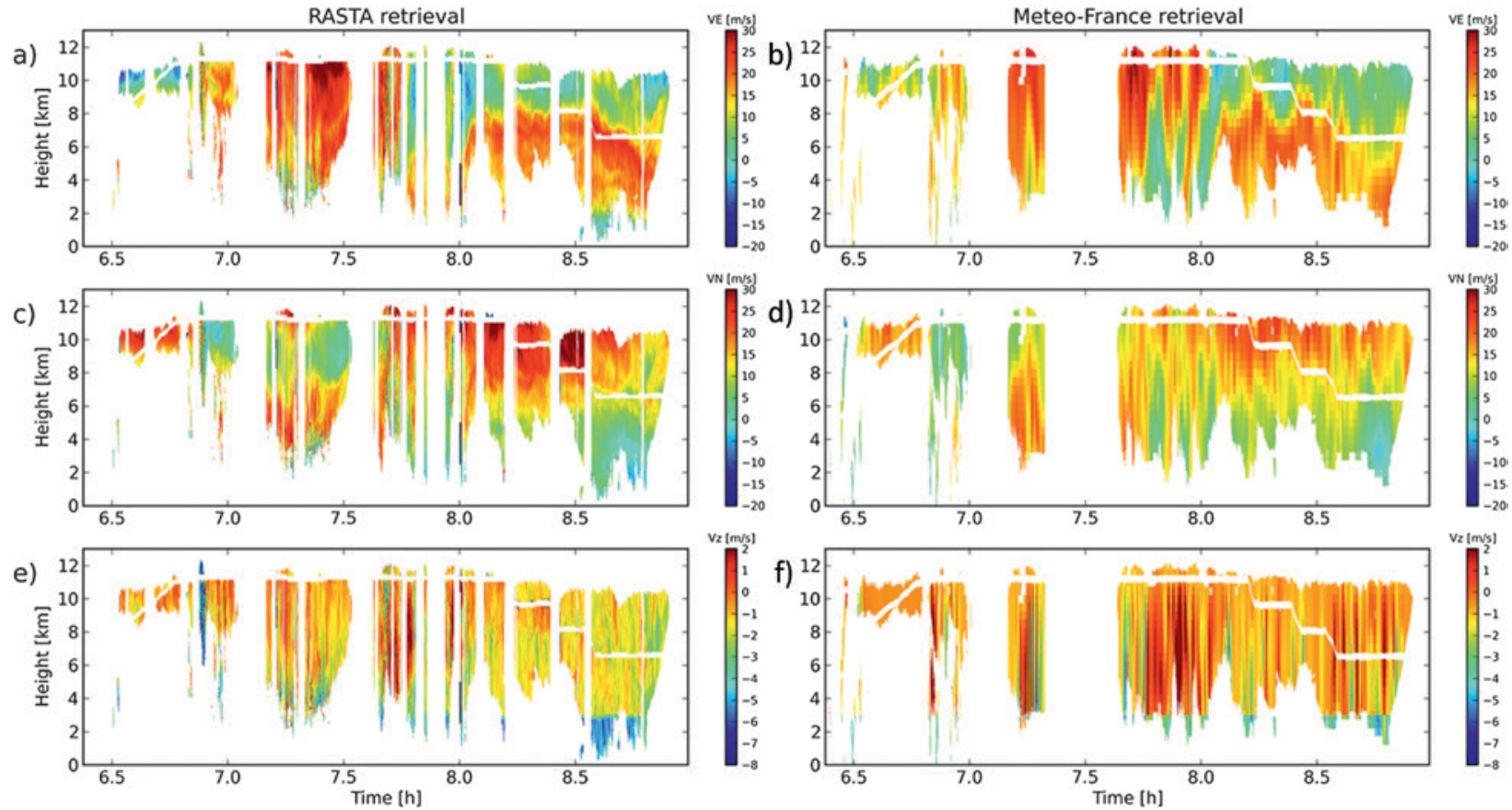

FIG. 7. Preliminary comparisons between (left) RASTA-derived winds and (right) 3D MDWs between 0630 and 0900 UTC 24 Sep 2012: (a),(b) zonal, (c),(d) meridional, and (e),(f) vertical wind components. Multiple-Doppler data are extracted along the flight track at the closest location of the antenna beam.
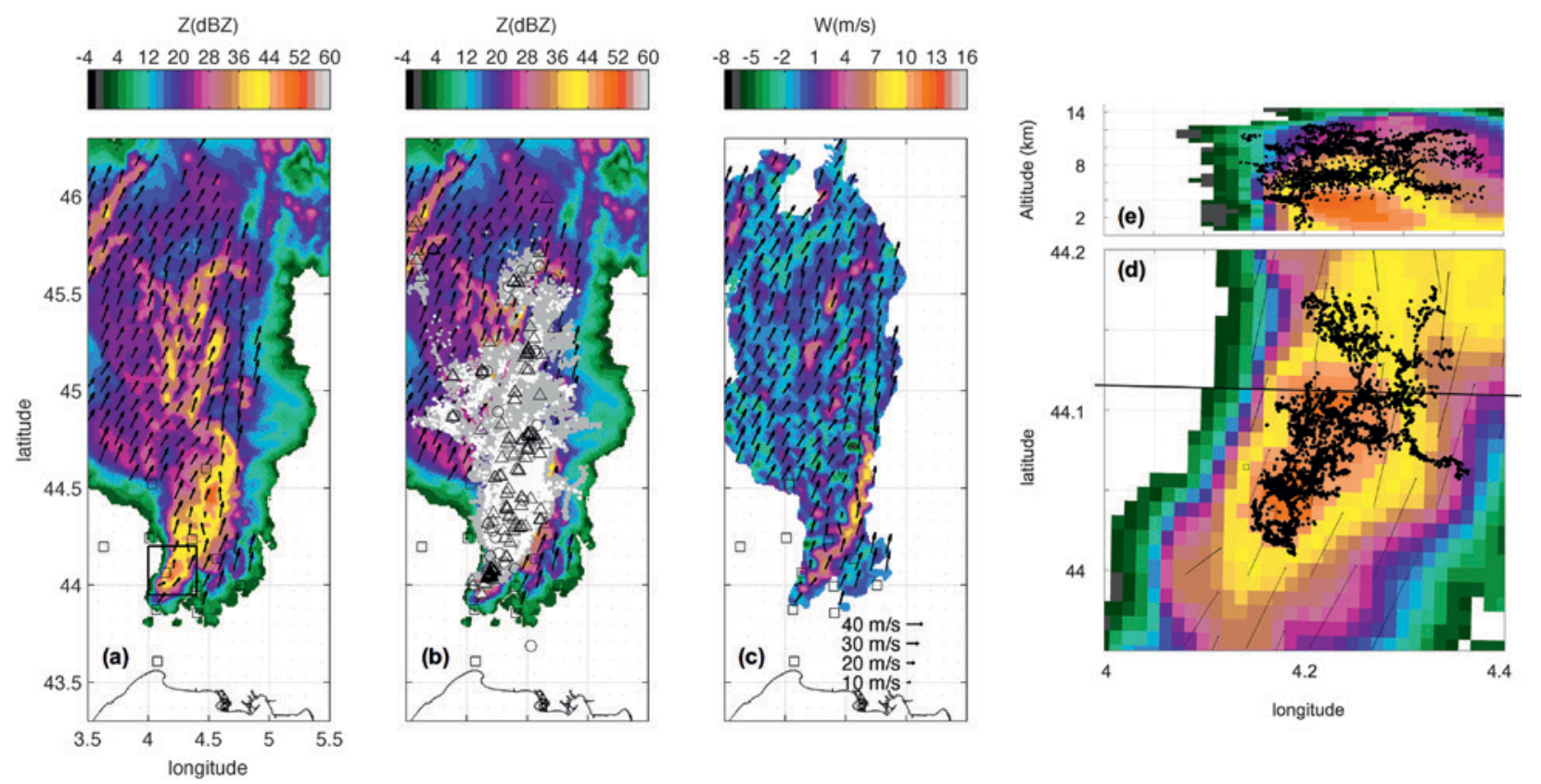

FIG. 8. (a) Reflectivity and horizontal wind at $5 \mathrm{~km}$ MSL from 3D MDWs and reflectivity analysis from 0215 to 0230 UTC 24 Sep 2012. (b) Overlay of lightning activity as recorded by LMA (in gray along the depth of the $500-\mathrm{m}$ reflectivity layer; in white over the entire atmospheric column) and EUCLID (negative CG strokes as triangles; positive CG strokes as circles) during $15 \mathrm{~min}$. (c) Vertical velocity. (d) A zoom-in of the domain drawn in (a) with lightning observations collected at 0229:06-0229:16, where seven flashes were recorded by the LMA including one negative CG flash in the considered domain. (e) Vertical distribution of the VHF sources overlaid on the vertical cross section of reflectivity along the black line drawn in (d). 


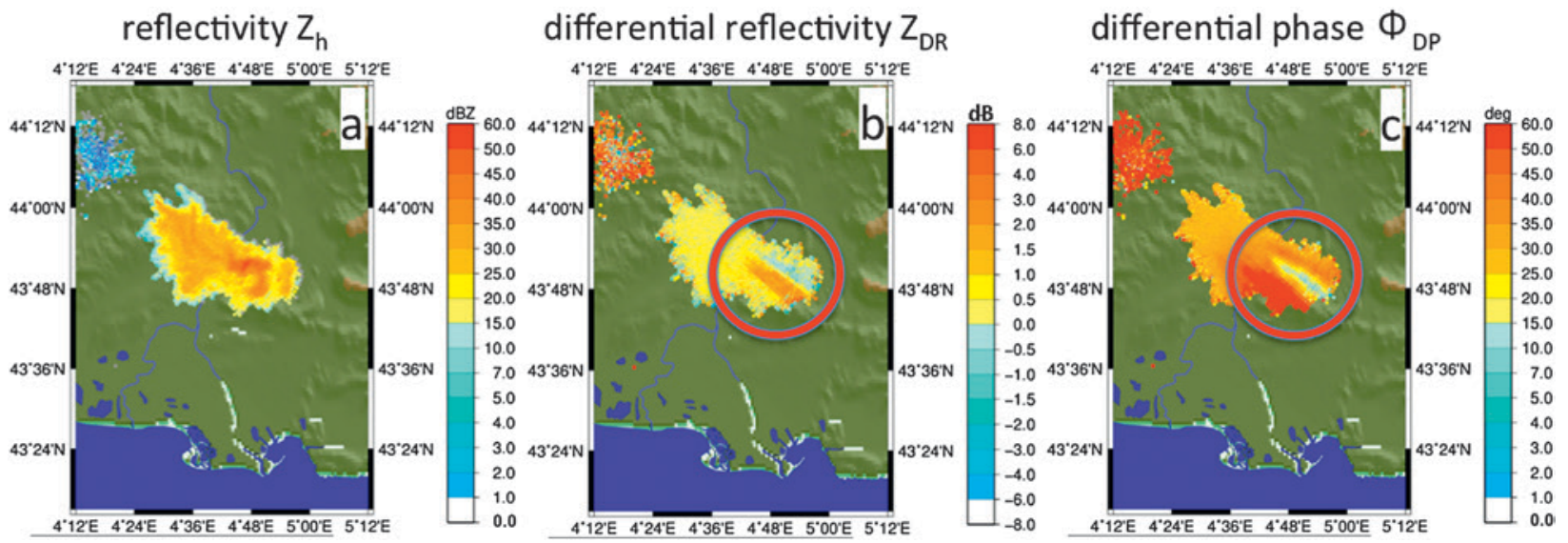

FIG. 9. (a) Reflectivity, (b) differential reflectivity, and (c) differential phase sampled by NOXP at I845 UTC 21 Oct 2012 at an elevation angle of $6.4^{\circ}$. The red circles highlight depolarization signatures potentially indicating strong electrification in the storm.

TOWARD THE ASSIMILATION OF NEW RADAR OBSERVATIONS. Dual-polarimetric observations. An expected outcome of the HyMeX project is to thoroughly assess the quality of dualpolarimetric radar measurements as well as to investigate new avenues for their utilization in operational weather forecasts. Specifically, this objective includes the development of data assimilation techniques to ingest dual-polarimetric radar data into convection-permitting NWP models. A necessary step for data assimilation was the development of a flexible, fully featured radar simulator of polarimetric radar variables (e.g., Jung et al. 2008; Pfeifer et al. 2008; Ryzhkov et al. 2011) within the mesoscale, nonhydrostatic atmospheric model Méso-NH (Lafore et al. 1998) to enable direct comparisons between model-simulated and observed polarimetric radar variables. The newly developed polarimetric radar simulator, which is based on the conventional radar simulator of Caumont et al. (2006), calculates electromagnetic wave propagation and scattering at $\mathrm{S}, \mathrm{C}$, and $\mathrm{X}$ bands and considers beam propagation effects, such as (differential) attenuation and phase shift, and beam refraction and broadening. It is fully consistent with the microphysical parameterizations of the Méso-NH model, which uses a single-moment bulk microphysical scheme governing the equations of the six following water species: vapor, cloud water, liquid water, graupel, snow, and pristine ice. It can be used to simulate all polarimetric observables, such as reflectivity at horizontal polarization, $Z_{\mathrm{DR}}$, $\Phi_{\mathrm{DP}}$, and specific differential phase shift $\left(K_{\mathrm{DP}}\right)$, as well as cross-correlation coefficient and differential backscattering phase, among others.
An example of observed and simulated polarimetric variables is shown in Fig. 10 for the IOP 6 bow echo system. According to observed (Figs. 10a,c,e) and simulated (Figs. 10b,d,f) polarimetric data, the MCS appears reasonably well reproduced by the model although one can note that the convective line is slightly shifted northwestward and that the simulated values are lower than their observed counterparts. These spatiotemporal lags and biases will be considered "innovations" in a data assimilation context, providing needed information to adjust model-state variables and improve forecasts at later times. Future work with these datasets will identify the most useful polarimetric observables for data assimilation purposes and will eventually establish the degree to which their assimilation improves short-term forecasts of heavy precipitation events.

Real-time radar refractivity retrieval. Radar refractivity measurements consist of using the signal returned by ground clutter to estimate the refractive index, which is related to surface pressure, temperature, and especially humidity (Fabry et al. 1997). These observations represent a unique dataset that can be used to map the distribution of low-level moisture, a key parameter for understanding convection initiation and evolution (Besson et al. 2012; Besson and Parent du Chatelet 2013).

The HyMeX campaign was chosen as a test bed for real-time refractivity retrievals by Météo-France. The refractivity retrieval algorithms of Fabry et al. (1997) and Fabry (2004) were first adapted to the characteristics of French operational radars, all of which are equipped with magnetron transmitters (Parent du Châtelet et al. 2012) and then applied to three 
operational S-band radars (Nîmes, Bollène, and Opoul) located in southern France (Fig. 1a). Refractivity retrievals were evaluated through comparisons with automatic weather stations (AWS; Fig. 11) as well as NWP outputs using the observation operator described by Caumont et al. (2013). The good agreement between radar-measured, observed, and model-simulated refractivity demonstrate the ability to achieve real-time, accurate, low-level refractivity measurements from noncoherent weather radars, and it definitely paves the way for assimilating radar refractivity measurements in convection-permitting NWP models.
SUMMARY AND OUTLOOK. The ongoing deployment of operational and research polarimetric radar systems throughout the planet allow for a whole new world of challenges to the international radar community. In this regard, the radar observations collected in southern France during HyMeX SOP 1 represent a valuable, and potentially unique, dataset that can be used to improve our knowledge of physical processes at play within coastal orographic heavy precipitating systems, but also to develop, and to evaluate, novel radar-based products for research and operational activities. For this reason, radar data collected by in-

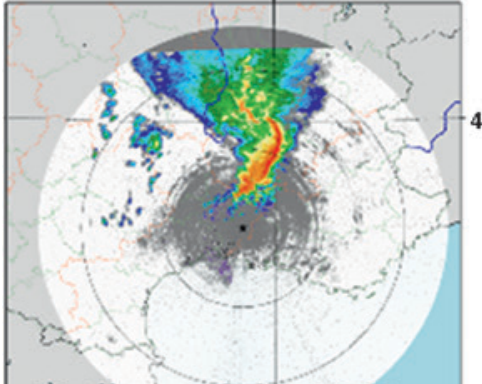

(a) Öbserved Zhh (dBZ)
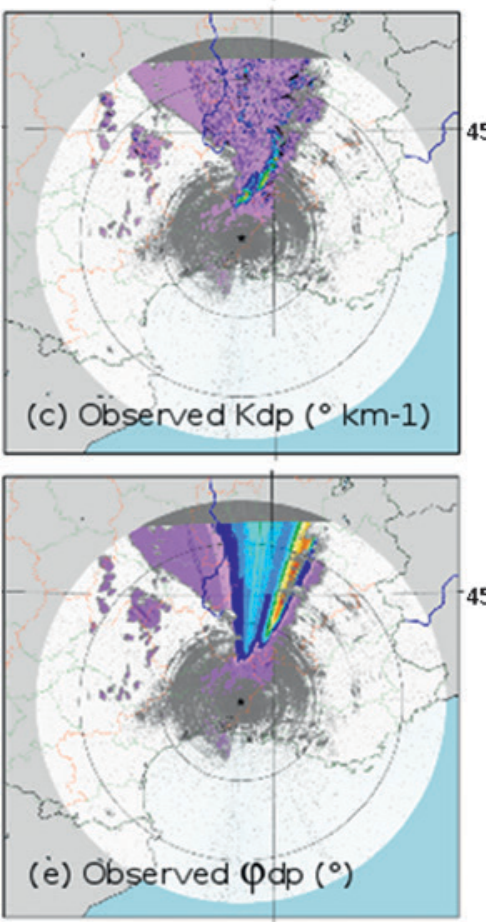

$5^{\circ} \mathrm{E}$
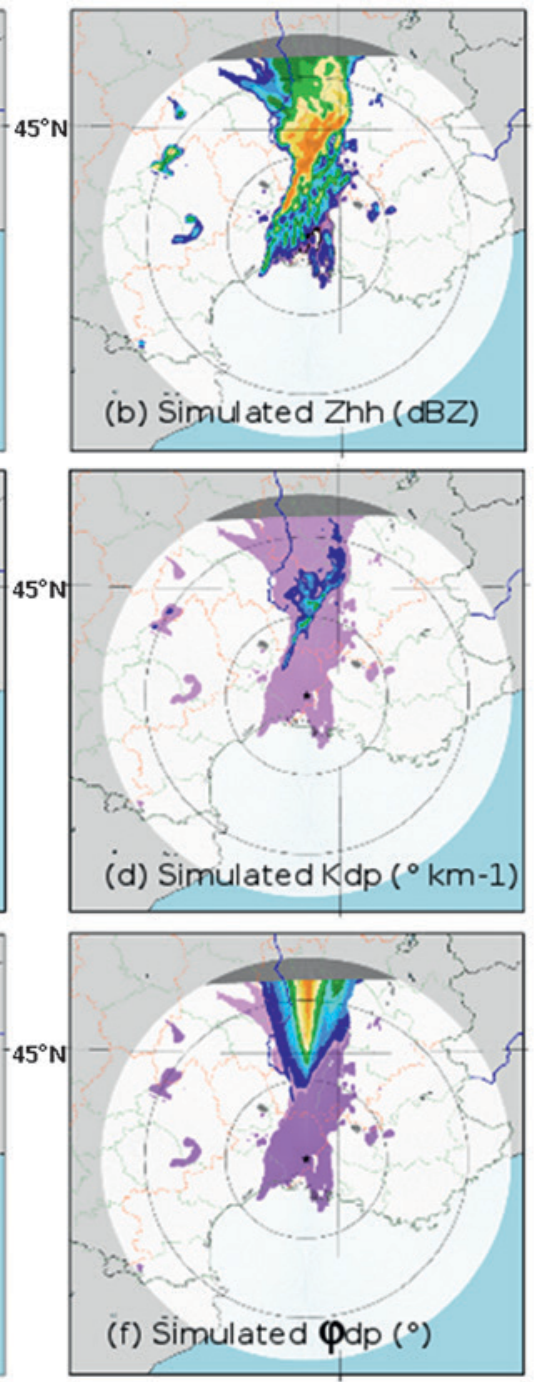

$5^{\circ} \mathrm{E}$

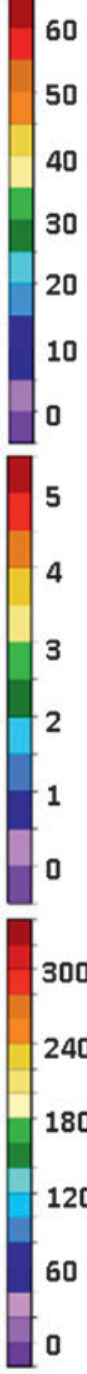

300

240

180

120

60

0

FIG. 10. (left) Observed and (right) simulated PPIs of polarimetric variables at an elevation of $0.6^{\circ}$ for the Nimes radar, valid at 0300 UTC 24 Sep 2012: (a),(b) reflectivity (dBZ), (c),(d) specific differential phase $\left({ }^{\circ} \mathrm{km}^{-1}\right)$, and (e),(f) differential phase $\left({ }^{\circ}\right)$. Range rings indicate distances of 100 and $200 \mathrm{~km}$ from the radar. White corresponds to reflectivity value below the noise level, while gray indicates nonmeteorological echoes (for radar images), or data outside the domain of simulation (model images).

ternational teams involved in the project have all been made freely available in the HyMeX database (http:// mistrals.sedoo.fr/HyMeX/) for noncommercial research and educational outreach activities. The use and dissemination of these data and products are encouraged by all radar scientists to foster collaborations and discussions between international research teams from all over the world.

The HyMeX 10-yr concerted experimental effort, which has brought together more than 400 scientists from all over the world, will last until 2020 (Drobinski et al. 2014). Although no new field phase is expected at the moment, the HyMeX database will continue to be regularly enhanced with new observations from operational weather services and local field experiments. Collaborations and discussions between scientists will also continue under the auspices of the HyMeX international workshop series, which has been organized every year since 2007.

\section{ACKNOWLEDGMENTS.}

We wish to thank all the scientists who contributed to 


\section{Nîmes Garons - 30258001}

\section{Automatic Weather Station, Radar and AROME-WMed Intercomparison}

— Radar

- Automatic Weather Station

- Arome-WMed Analysis

- Arome-WMed background

- Precipitations

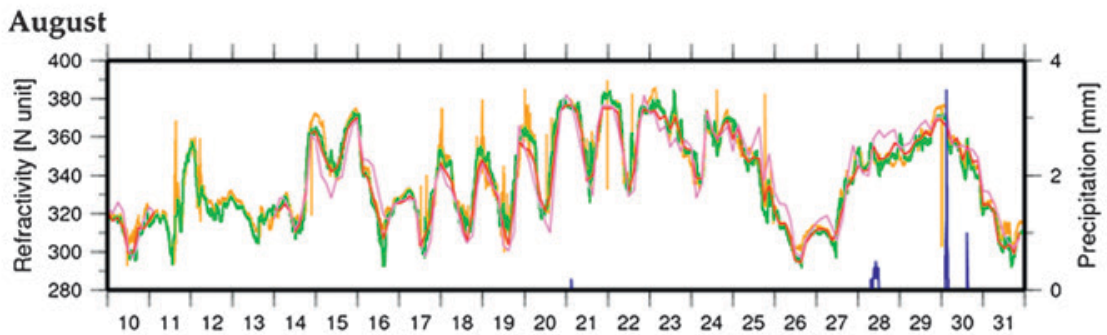

September

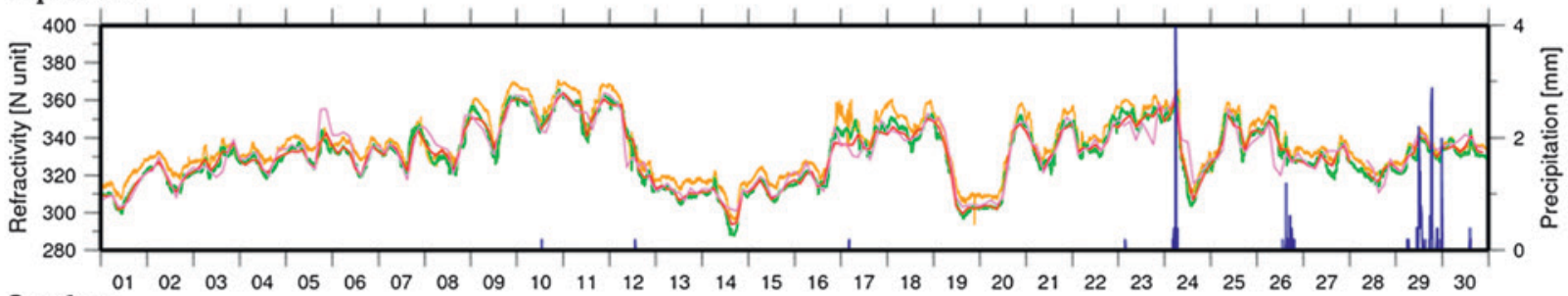

October

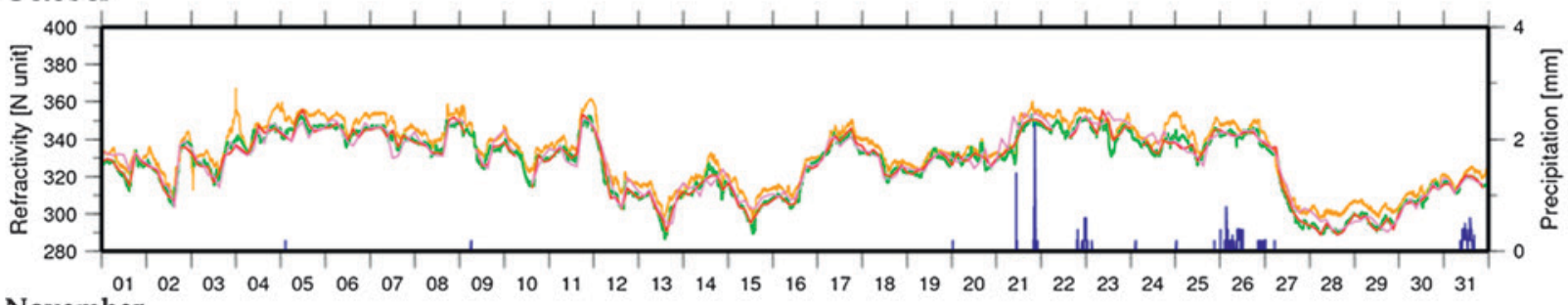

November

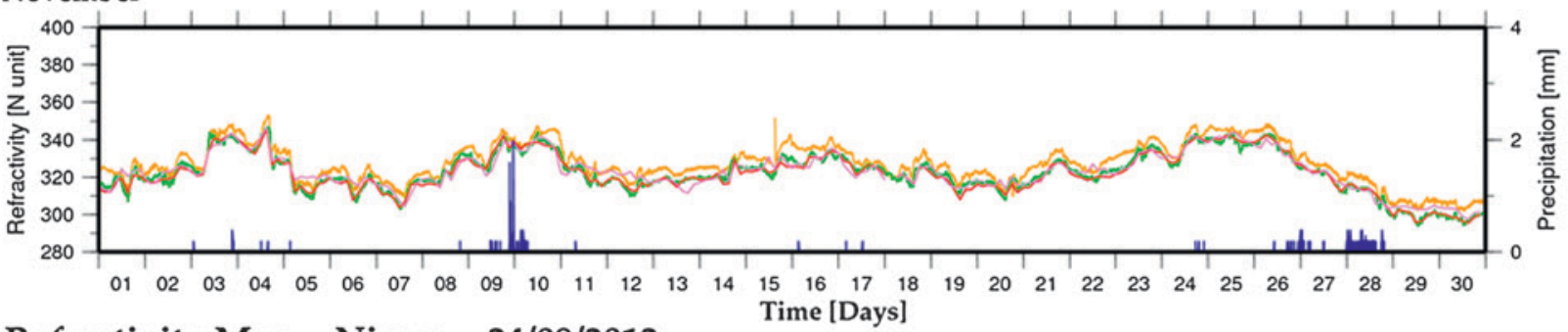

Refractivity Map - Nimes - 24/09/2012
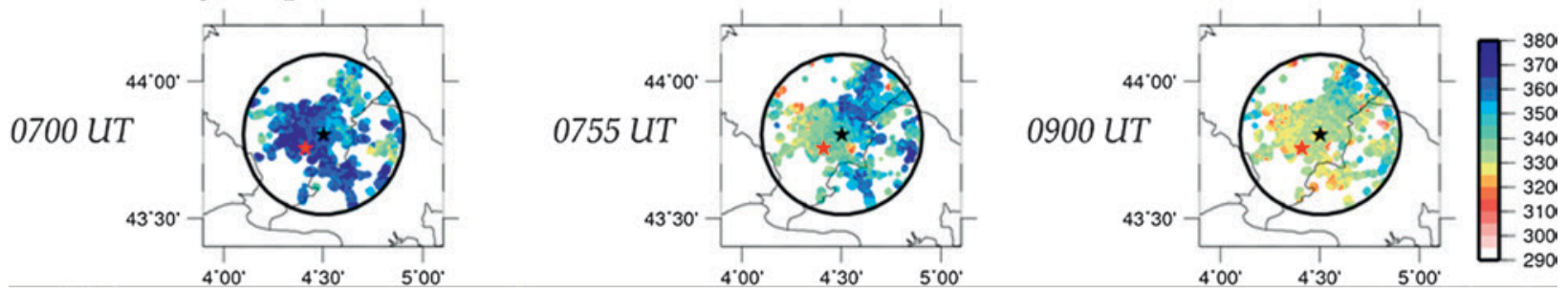

FIG. II. (top) Time series of radar (orange), AWS (green), and model-derived refractivity between I0 Aug and 30 Nov 2012 at Nîmes-Garons airport. The blue curve corresponds to 5-min rainfall rates. (bottom) The three refractivity maps show the evolution of air masses on 24 Sep 2012 at (left) 0700, (middle) 0755, and (right) 0900 UTC. High refractivity values, corresponding to cold and/or wet air masses, are progressively replaced by lower values, which are indicative of warm and/or dry air resulting from the advection of cold air associated with the passage of an eastward-propagating cold front over the radar. The black (red) star corresponds to the location of the radar (Nîmes-Garons AWS).

the realization of the HyMeX radar component. A special mention is due to the members of Météo-France's operational observation division, who managed to provide operational data to the HyMeX community-B. Fradon, H. Al-Sakka, A.-A. Boumahmoud, J. Parent-du-Chatelet, and P. Tabary-and to scientists S. Coquillat, M. Hagen, 
L. Labatut, Y Lemaître, and Y. Pointin and to students E. Fontaine, F. Pantillon, and T. Wisman, who participated in field operations and preliminary data analysis. HyMeX SOP 1 was supported by CNRS, Météo-France, CNES, IRSTEA, and INRA through the large interdisciplinary international program Mediterranean Integrated Studies at Regional and Local Scales (MISTRALS), which is dedicated to the understanding of the Mediterranean basin environmental process (www.mistrals-home.org). The radar component of HyMeX SOP 1 was sponsored by Grants ANR2011-BS56-027 FLOODSCALE and ANR-11-BS56-0005 IODA-MED.

\section{REFERENCES}

Al-Sakka, H., A.-A. Boumahmoud, B. Fradon, S. Frasier, and P. Tabary, 2013: A new fuzzy logic hydrometeor classification scheme applied to the French X-, C-, and S-band polarimetric radars. J. Appl. Meteor. Climatol., 52, 2328-2344, doi:10.1175/JAMC-D-12-0236.1.

Barthe, C., M. Chong, J.-P. Pinty, C. Bovalo, and J. Escobar, 2012: CELLS v1.0: Updated and parallelized version of an electrical scheme to simulate multiple electrified clouds and flashes over large domains. Geosci. Model Dev., 5, 167-184, doi:10.5194/gmd -5-167-2012.

Beck, J., and O. Bousquet, 2013: Using gap-filling radars in mountainous regions to complement a national radar network: Improvements in multiple-Doppler wind syntheses. J. Appl. Meteor. Climatol., 52, 1836-1850, doi:10.1175/JAMC-D-12-0187.1.

—, M. Nuret, and O. Bousquet, 2014: Model wind field forecast verification using multipleDoppler syntheses from a national radar network. Wea. Forecasting, 29, 331-348, doi:10.1175/WAF -D-13-00068.1.

Besson, L., and J. Parent du Châtelet, 2013: Solutions for improving the radar refractivity measurement by taking operational constraints into account. J. Atmos. Oceanic Technol., 30, 1730-1742, doi:10.1175 /JTECH-D-12-00167.1.

— , C. Boudjabi, O. Caumont, and J. Parent du Châtelet, 2012: Links between weather phenomena and characteristics of refractivity measured by Precipitation Radar. Bound-Layer Meteor., 143, 77-95, doi:10.1007/s10546-011-9656-7.

Bougeault, P., and Coauthors, 2001: The MAP special observing period. Bull. Amer. Meteor. Soc., 82, 433-462, doi:10.1175/1520-0477(2001)0822.3.CO;2.

Bousquet, O., and P. Tabary, 2014: Development of a nationwide real-time 3-D wind and reflectivity radar composite in France. Quart. J. Roy. Meteor. Soc., 140, 611-625, doi:10.1002/qj.2163.
- — - a and J. Parent du Châtelet, 2007: On the value of operationally synthesized multipleDoppler wind fields. Geophys. Res. Lett., 34, L22813, doi:10.1029/2007GL030464.

—, T. Montmerle, and P. Tabary, 2008a: Using operationally synthesized multiple-Doppler winds for high resolution NWP model horizontal wind verification. Geophys. Res. Lett., 35, L10803, doi:10.1029/2008GL033975.

—, P. Tabary, and J. Parent du Châtelet, 2008b: Operational multiple-Doppler wind retrieval inferred from long range radar velocity measurements. J. Appl. Meteor. Climatol., 47, 2929-2945, doi:10.1175/2008JAMC1878.1.

Caumont, O., V. Ducrocq, G. Delrieu, M. Gosset, J.-P. Pinty, J. Parent du Châtelet, and G. Scialom, 2006: A radar simulator for high-resolution nonhydrostatic models. J. Atmos. Oceanic Technol., 23, 1049-1067, doi:10.1175/JTECH1905.1.

— A. Foray, L. Besson, and J. Parent du Châtelet, 2013: Comparisons between observed and simulated weather radar refractivity change. Bound.Layer Meteor., 148, 379-397, doi:10.1007/s10546-013 $-9820-3$.

Davis, C., and Coauthors, 2004: The Bow Echo and MCV Experiment: Observations and opportunities. Bull. Amer. Meteor. Soc., 85, 1075-1093, doi:10.1175 /BAMS-85-8-1075.

Deierling, W., W. A. Petersen, J. Latham, S. Ellis, and H. J. Christian, 2008: The relationship between lightning activity and ice fluxes in thunderstorms. J. Geophys. Res., 113, D15210, doi:10.1029/2007JD009700.

Delanoë, J., A. Protat, D. Bouniol, A. Heymsfield, A. Bansemer, and P. Brown, 2007: The characterization of ice cloud properties from Doppler radar measurements. J. Appl. Meteor. Climatol., 46, 1682-1698, doi:10.1175/JAM2543.1.

Delrieu, G., 2003: L'Observatoire Hydro-météorologique Méditerranéen Cévennes-Vivarais (The CévennesVivarais Mediterranean Hydrometeorological Observatory). Houille Blanche, 6, 83-88, doi:10.1051 /lhb/2003116.

- , and Coauthors, 2005: The catastrophic flash-flood event of 8-9 September 2002 in the Gard Region, France: A first case study for the Cévennes-Vivarais Mediterranean Hydrometeorological Observatory. J. Hydrometeor., 6, 34-52, doi:10.1175/JHM-400.1.

Dolan, B., S. A. Rutledge, S. Lim, V. Chandrasekar, and M. Thurai, 2013: A robust C-band hydrometeor identification algorithm and application to a long-term polarimetric radar dataset. J. Appl. Meteor. Climatol., 52, 2162-2186, doi:10.1175/JAMC -D-12-0275.1. 
Drobinski, P., and Coauthors, 2014: HyMeX: A 10-year multidisciplinary program on the Mediterranean water cycle. Bull. Amer. Meteor. Soc., 95, 1063-1082, doi:10.1175/BAMS-D-12-00242.1.

Ducrocq, V., and Coauthors, 2014: HyMeX-SOP1: The field campaign dedicated to heavy precipitation and flash flooding in the northwestern Mediterranean. Bull. Amer. Meteor. Soc., 95, 1083-1100, doi:10.1175 /BAMS-D-12-00244.1.

Dufournet, Y., and H. W. J. Russchenberg, 2011: Towards the improvement of cloud microphysical retrievals using simultaneous Doppler and polarimetric radar measurements. Atmos. Meas. Tech., 4, 2163-2178, doi:10.5194/amt-4-2163-2011.

Fabry, F., 2004: Meteorological value of ground target measurements by radar. J. Atmos. Oceanic Technol., 21, 560-573, doi:10.1175/1520-0426 (2004)0212.0.CO;2.

—, C. Frush, I. Zawadzki, and A. Kilambi, 1997: On the extraction of near-surface index of refraction using radar phase measurements from ground targets. J. Atmos. Oceanic Technol., 14, 978-987, doi:10.1175/1520-0426(1997)0142.0.CO;2.

Fujita, T. T., 1978: Manual of downburst identification for project NIMROD. Satellite and Mesometeorology Research Paper 156, Dept. of Geophysical Sciences, University of Chicago, $104 \mathrm{pp}$.

Hubbert, J. C., S. M. Ellis, M. Dixon, and G. Meymaris, 2010: Modeling, error analysis, and evaluation of dual-polarization variables obtained from simultaneous horizontal and vertical polarization transmit radar. Part II: Experimental data. J. Atmos. Oceanic Technol., 27, 1599-1607, doi:10.1175/2010JTECHA1337.1.

Jung, Y., G. Zhang, and M. Xue, 2008: Assimilation of simulated polarimetric radar data for a convective storm using the ensemble Kalman filter. Part I: Observation operators for reflectivity and polarimetric variables. Mon. Wea. Rev., 136, 2228-2245, doi:10.1175/2007MWR2083.1.

Kirstetter, P.-E., H. Andrieu, B. Boudevillain, and G. Delrieu, 2013: A physically based identification of vertical profiles of reflectivity from volume scan radar data. J. Appl. Meteor. Climatol., 52, 1645-1663, doi:10.1175/JAMC-D-12-0228.1.

Kruger, A., and W. Krajewski, 2002: Two-dimensional video disdrometer: A description. J. Atmos. Oceanic Technol., 19, 602-617, doi:10.1175/1520 -0426(2002)0192.0.CO;2.

Lafore, J.-P., and Coauthors, 1998: The Meso-NH Atmospheric Simulation System. Part I: Adiabatic formulation and control simulations. Ann. Geophys., 16, 90-109, doi:10.1007/s00585-997-0090-6.
Löffler-Mang, M., and J. Joss, 2000: An optical disdrometer for measuring size and velocity of hydrometeors. J. Atmos. Oceanic Technol., 17, 130-139, doi:10.1175/1520-0426(2000)0172.0.CO;2.

_-, M. Kunz, and W. Schmid, 1999: On the performance of a low-cost K-band Doppler radar for quantitative rain measurements. J. Atmos. Oceanic Technol., 16, 379-387, doi:10.1175/1520 -0426(1999)0162.0.CO;2.

Marzano F. S., D. Scaranari, M. Celano, P. P. Alberoni, G. Vulpiani, and M. Montopoli, 2006: Hydrometeor classification from dual-polarized weather radar: Extending fuzzy logic from S-band to C-band data. Adv. Geosci., 7, 109-114, doi:10.5194/adgeo-7-109-2006.

Medina, S., B. F. Smull, R. A. Houze Jr., and M. Steiner, 2005: Cross-barrier flow during orographic precipitation events: Results from MAP and IMPROVE. J. Atmos. Sci., 62, 3580-3598, doi:10.1175/JAS3554.1.

Parent du Châtelet, J., C. Boudjabi, L. Besson, and O. Caumont, 2012: Errors caused by long-term drifts of magnetron frequencies for refractivity measurement with a radar: Theoretical formulation and initial validation. J. Atmos. Oceanic Technol., 29, 1428-1434, doi:10.1175/JTECH-D-12-00070.1.

Park, H. S., A. V. Ryzhkov, D. S. Zrnić, and K. E. Kim, 2009: The hydrometeor classification algorithm for the polarimetric WSR-88D: Description and application to an MCS. Wea. Forecasting, 24, 730748, doi:10.1175/2008WAF2222205.1.

Pfeifer, M., G. Craig, M. Hagen and C. Keil, 2008: A polarimetric radar forward operator for model evaluation. J. Appl. Meteor. Climatol., 47, 3202-3220, doi:10.1175/2008JAMC1793.1.

Pinty, J.-P., C. Barthe, E. Defer, E. Richard, and M. Chong, 2013: Explicit simulation of electrified clouds: From idealized to real case studies. Atmos. Res., 123, 82-92, doi:10.1016/j.atmosres.2012.04.008.

Protat, A., and Coauthors, 2009: Assessment of Cloudsat reflectivity measurements and ice cloud properties using ground-based and airborne cloud radar observations. J. Atmos. Oceanic Technol., 26, 1717-1741, doi:10.1175/2009JTECHA1246.1.

Rison, W., R. J. Thomas, P. R. Krehbiel, T. Hamlin, and J. Harlin, 1999: A GPS-based three-dimensional lightning mapping system: Initial observations in central New Mexico. Geophys. Res. Lett., 26, 3573-3576, doi:10.1029/1999GL010856.

Rotunno, R., and R. A. Houze, 2007: Lessons on orographic precipitation from the Mesoscale Alpine Programme. Quart. J. Roy. Meteor. Soc., 133, 811830, doi:10.1002/qj.67.

Ryzhkov, A. V., and D. S. Zrnić, 2007: Depolarization in ice crystals and its effect on radar polarimetric 
measurements. J. Atmos. Oceanic Technol., 24, 1256-1267, doi:10.1175/JTECH2034.1.

—, M. Pinsky, M. Pokrovsky, and A. Khain, 2011: Polarimetric radar observation operator for a cloud model with spectral microphysics. J. App. Meteor. Climatol., 50, 873-894, doi:10.1175/2010JAMC2363.1.

Schultz, D. M., and Coauthors, 2002: Understanding Utah winter storms: The Intermountain Precipitation Experiment. Bull. Amer. Meteor. Soc., 83, 189-210, doi:10.1175/1520-0477(2002)0832.3.CO;2.

Stoelinga, M. T., and Coauthors, 2003: Improvement of Microphysical Parameterization through Observational Verification Experiment. Bull. Amer.
Meteor. Soc., 84, 1807-1826, doi:10.1175/BAMS-84 $-12-1807$.

Unal, C., 2009: Spectral polarimetric radar clutter suppression to enhance atmospheric echoes. $J$. Atmos. Oceanic Technol., 26, 1781-1797, doi:10.1175 /2009JTECHA1170.1.

— - Y. Dufournet, T. Otto, and H. Russchenberg, 2012: The new real-time measurement capabilities of the profiling TARA radar. Preprints, Seventh European Conf. on Radar in Meteorology and Hydrology (ERAD), Toulouse, France, Météo-France, 199 SP. [Available online at www.meteo.fr/cic/meetings/2012ERAD lextended_abs/SP_388_ext_abs.pdf.]

\section{BEST SELLER!}

" Here before you is the complete guide to writing a good scientific paper.... Prepare to absorb what may prove the most valuable advice you will receive as a scientist."

— from the Foreword by Prof. Kerry Emanuel, Massachusetts Institute of Technology

\section{Eloquent Science:}

\section{A Practical Guide to Becoming a Better Writer, Speaker, and Atmospheric Scientist} DAVID M. SCHULTZ

What started out as a communications workshop for undergrads in atmospheric science evolved into a book that would benefit scientists at any stage in their careers. Drawing on Schultz's experience as a journal editor and prolific writer, the insights of his colleagues, and the best advice from hundreds of sources, this must-have reference includes:

- Tips for writing and reviewing scientific papers and a peek into the operations of the publishers of scientific journals

- Guidance on creating and delivering effective scientific presentations

- Experts' advice on citing others' work, critiquing scientific papers, communicating with the media, and more

LIST \$45 MEMBER \$30 @ 2009, PAPERBACK, 440 PAGES, ISBN 13: 978-1-878220-91-2, AMS CODE: ESCI

ORDER TODAY!

ONLINE AMS BOOKSTORE WWW.ametsOc.org/amshookstore on use the order form in this magazine
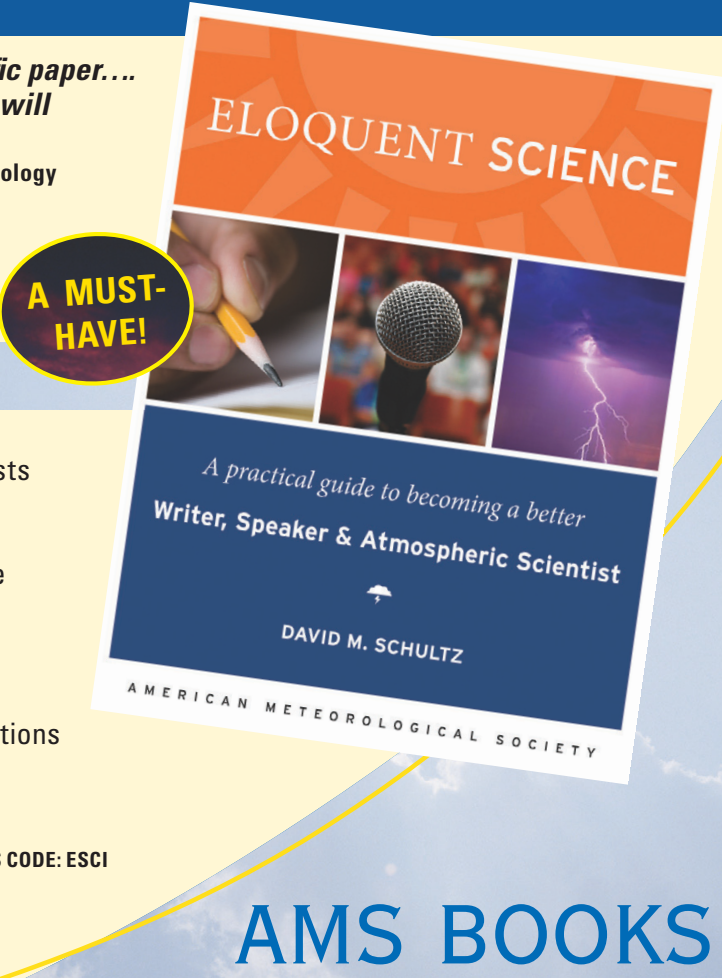

RESEARCH APPLICATIONS HISTORY 